\title{
Aminosquaraines as potential photodynamic agents: Synthesis and evaluation of in vitro cytotoxicity
}

\author{
Álvaro F. Magalhães ${ }^{a}$, Vânia C. Graça ${ }^{a}$, Ricardo C. Calhelha ${ }^{b}$, Isabel C.F.R. Ferreira ${ }^{b, *}$, Paulo F. Santos ${ }^{a, *}$ \\ ${ }^{a}$ Chemistry Dep. and Chemistry Center - Vila Real (CQ-VR), University of Trás-os-Montes and Alto Douro, 5001-801 Vila Real, Portugal \\ ${ }^{\mathrm{b}}$ Mountain Research Centre (CIMO), Polytechnic Institute of Bragança, Campus de Santa Apolónia, 5300-253 Bragança, Portugal
}

\section{A R T I C L E I N F O}

\section{Article history:}

Received 4 July 2017

Revised 31 July 2017

Accepted 2 August 2017

Available online 3 August 2017

\section{Keywords:}

Photodynamic therapy

Cancer

Photosensitizer

Squaraine dyes

\begin{abstract}
A B S T R A C T
The synthesis of several aminosquaraine cationic dyes displaying strong absorption within the so-called phototherapeutic window $(650-850 \mathrm{~nm})$ is described. Their cytotoxicity, under dark and illuminated conditions, was tested against several human tumor cell lines (breast, lung, cervical and hepatocellular carcinomas) and non-tumor porcine liver primary cells. All compounds showed to inhibit the growth of the tumor cells upon irradiation more than in the absence of light, in more or less extension, clearly exhibiting photodynamic activity. The photosensitizing ability against some cell lines, together with the low toxicity for the non-tumor primary PLP2 cells displayed by some of the compounds synthetized, turns them into potential candidates as photosensitizers for PDT.
\end{abstract}

(c) 2017 Elsevier Ltd. All rights reserved.

\section{Introduction}

Photodynamic therapy (PDT) is a promising minimally invasive therapeutic technique that has been shown effective for cancer and other non-oncological conditions [1]. It is based on the use of a sensitizer that, after accumulating inside the abnormal cells, is excited by light of an appropriate wavelength and interacts with oxygen, leading to the production of reactive oxygen species (ROS) which induce cell death via oxidative stress mechanisms. Amongst those, singlet oxygen is generally considered to be the main cytotoxic agent responsible for the photodynamic effect [2]. The prerequisite of concurrence of this triad of components (photosensitizer, oxygen and light), which individually are innocuous, for the photodynamic process to take place turns PDT a particularly selective modality, with unique advantages compared to conventional tumor therapies such as surgery, chemotherapy and radiotherapy $[3,4]$.

Photofrin $^{\circledR}$, a mixture of hematoporphyrin derivatives, was the first photosensitizer to be approved by the regulatory agencies and still the most extensively used for medical applications of PDT [5]. This so-called first generation sensitizer presents however several drawbacks, namely a lack of chemical homogeneity, prolonged coetaneous photosensitivity and a less than optimal light absorption profile $\left(\lambda=630 \mathrm{~nm}, \varepsilon=3200 \mathrm{M}^{-1} \mathrm{~cm}^{-1}\right)$ [6], which

\footnotetext{
* Corresponding authors.

E-mail addresses: iferreira@ipb.pt (I.C.F.R. Ferreira), psantos@utad.pt (P.F. Santos).
}

entails the use of higher drug dosages, and limits the penetration depth of light into tissue.

The crucial role of the photosensitizer in the success of PDT turned the development of new sensitizers with better photophysical and photobiological properties into an active area of research in the two last decades and a lot of attention has been given to a number of different classes of compounds as potential so-called second generation sensitizers [5,7].

Squaraines, a class of functional dyes with sharp and intense visible to NIR absorption which have found wide application in the domain of photonics [8], have also attracted great interest as a new class of potential photosensitizers for PDT [9] since, in 1997, Ramaiah et al. [10] synthesized and investigated the photophysical properties, including the singlet oxygen generation ability, of some squaraines derived from phloroglucinol. As a result, a lot of work has been published on the structural variation of squaraines which, however, has been mainly focused on the variation of the nature and substitution of the heterocyclic terminal groups [11]. The derivatization of the central squaric core, on the other hand, has been poorly addressed and has been the focus of our research for some years [12-14].

Notwithstanding a considerable number of squaraine compounds has been designed and synthesized with the purpose of PDT sensitizers, the in vitro assessment of their photodynamic ability has been barely addressed [15-24]. The reports of in vivo evaluation are even scarcer [17,18,21,25-27].

In this work we synthesized several squaraine dyes substituted at the central four member ring with different amino groups and 
assessed their cytotoxicity, under dark and illuminated conditions, against several human tumor cell lines (breast, lung, cervical and hepatocellular carcinomas) and non-tumor porcine liver primary cells. These aminosquaraine dyes are envisioned to present some advantages over the common zwitterionic counterparts as their cationic character may positively influence cellular uptake taking advantage of the membrane potential, and the presence of amino groups, besides red-shifting the dye's absorption, may conveniently enhance solubility and interaction with the biological medium. To the best of our knowledge this is the first report on the in vitro photosensitizing ability of symmetrical aminosquaraine dyes.

Aminosquaraines $\mathbf{5}$ were synthesized from the zwitterionic dye 3 by an expeditious methodology developed earlier by some of us [12] (Scheme 1). The starting squaraine 3, easily prepared by the condensation of two molar equivalents of 2-methylbenzothiazolium salt 2 with squaric acid, in refluxing $n$-butanol/pyridine, was methylated with methyl triflate to furnish the crucial 0 -methyl intermediate 4 . The later then undergoes nucleophilic substitution with appropriate amines to yield the triflate analogues of 5. Each of the final compounds underwent counter-ion replacement by iodine, by treatment of a methanolic solution of the compound with excess $14 \%$ aqueous $\mathrm{KI}$, in order to take benefit from the so-called external heavy atom effect on the potential enhancement of singlet oxygen generation [28].

All the synthesized dyes exhibit sharp and intense absorption $\left(\varepsilon>10^{4} \mathrm{~cm}^{-1} \mathrm{M}^{-1}\right.$ ) in the red end of the visible spectrum, close to the bottom end of the phototherapeutic window (Table 1). In general, the amino-substituted dyes $\mathbf{5}$ display absorption at longer wavelengths than the starting non-substituted analogue $\mathbf{3}$. The chromophore shows typical donor-acceptor characteristics with increasing bathochromic shift as the electron donating properties of the auxochrome increases. The observed bathochromic shifts ranged from 3 to $22 \mathrm{~nm}$.

The cytotoxicity of the compounds synthesized was evaluated against four human tumor cell lines: breast (MCF-7), non-small cell lung (NCI-H460), cervical (HeLa) and hepatocellular (HepG2) carcinomas, and against a porcine liver primary cell culture (PLP2)
Table 1

Visible spectral data for squaraine dyes $\mathbf{3}$ and $\mathbf{5 a}-\mathbf{e}$.

\begin{tabular}{llll}
\hline Dye & $\mathrm{R}^{1}$ & $\mathrm{R}^{2}$ & $\lambda_{\max }{ }^{\mathrm{a}}(\mathrm{nm})(\log \varepsilon)$ \\
\hline $\mathbf{3}$ & - & - & $650(5.24)^{\mathrm{b}}$ \\
$\mathbf{5 a}$ & $\mathrm{H}$ & $\mathrm{H}$ & $648(5.41)$ \\
$\mathbf{5 b}$ & $\mathrm{H}$ & $\mathrm{CH}_{2} \mathrm{CH}_{2} \mathrm{OH}$ & $657(4.67)$ \\
$\mathbf{5 c}$ & $\mathrm{CH}_{2} \mathrm{CH}_{2} \mathrm{OH}$ & $\mathrm{CH}_{2} \mathrm{CH}_{2} \mathrm{OH}$ & $667(5.21)$ \\
$\mathbf{5 d}$ & $\mathrm{H}$ & $\mathrm{CH}_{3}$ & $658(5.23)^{\mathrm{b}}$ \\
$\mathbf{5 e}$ & $\mathrm{CH}_{3}$ & $\mathrm{CH}_{2} \mathrm{CH}_{2} \mathrm{OH}$ & $667(5.19)$ \\
\hline
\end{tabular}

Measured in $\mathrm{MeOH} / \mathrm{CH}_{2} \mathrm{Cl}_{2}(99 / 1)$.

b From Ref.[12]

established by some of us, both in the absence of light and under irradiation.

As a representative example, Fig. 1 shows the relative growth inhibition ability of dyes $\mathbf{5 a - e}$ on the human tumor cell lines studied using $0,1 \mu \mathrm{M}$ solutions of the dye, a concentration for which growth inhibition in the absence of light was less than $20 \%$ in all tests.

All compounds showed to inhibit the growth of the tumor cells upon irradiation more than in the dark, in more or less extension, clearly showing to display photocytotoxic effect. The more susceptible cell lines to phototoxicity were HeLa and MCF-7, for which the photodynamic treatment resulted in more significant differences in the growth inhibition of the cells in the dark and upon irradiation. Controls were set with the cells in the absence of the dyes in 3\% DMSO in DMEM and in the growth medium only. The cells were independently submitted to the photodynamic treatment and maintained in the dark. Neither DMSO alone, nor light alone, nor the combination of both was found to induce toxicity on the cells.

Although the study of the exact nature of the photodynamic action mechanism of the synthesized dyes is out of the scope of this work, it is worthwhile to mention that the majority of the compounds assayed have shown singlet oxygen generation ability $[14,29]$.

The $\mathrm{GI}_{50}$ values (compound concentration resulting in $50 \%$ of growth inhibition) determined for squaraine dyes $\mathbf{5 a - e}$ are presented in Table 2.<smiles>Cc1nc2ccccc2s1</smiles><smiles>CCCCCCC</smiles><smiles></smiles>
1
2<smiles>CCN1/C(=C/C2=C([O-])/C(=C/c3sc4ccccc4[n+]3CC)C2=O)Sc2ccccc21</smiles>

3<smiles>CCN1/C(=C/C2=C(OC)/C(=C/c3sc4ccccc4[n+]3CC)C2=O)Sc2ccccc21</smiles>

4

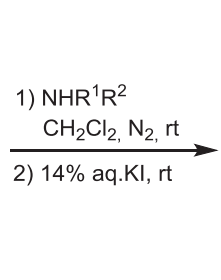<smiles>[R2]NC1=C(C=C2Sc3ccccc3N2CC)C(=O)C1=Cc1sc2ccccc2[n+]1CC</smiles>

5a $\mathrm{R}^{1}=\mathrm{R}^{2}=\mathrm{H}$

5b R $\mathbf{R}^{1}=\mathrm{H}, \mathrm{R}^{2}=\mathrm{CH}_{2} \mathrm{CH}_{2} \mathrm{OH}$

5c $\mathrm{R}^{1}=\mathrm{R}^{2}=\mathrm{CH}_{2} \mathrm{CH}_{2} \mathrm{OH}$

$5 d \mathrm{R}^{1}=\mathrm{H}, \mathrm{R}^{2}=\mathrm{CH}_{3}$

5e $\mathrm{R}^{1}=\mathrm{CH}_{3}, \mathrm{R}^{2}=\mathrm{CH}_{2} \mathrm{CH}_{2} \mathrm{OH}$ 
HeLa
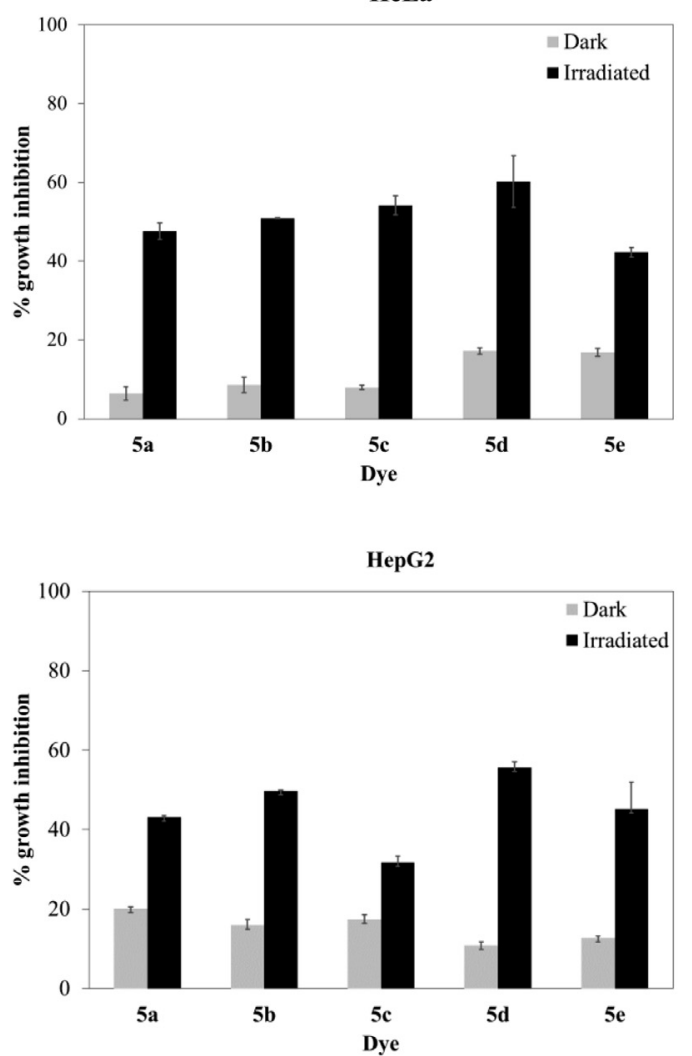

MCF-7

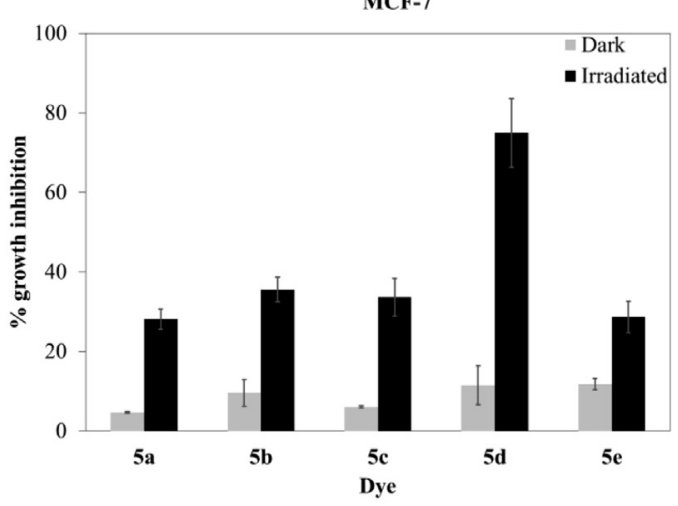

NCI-H460

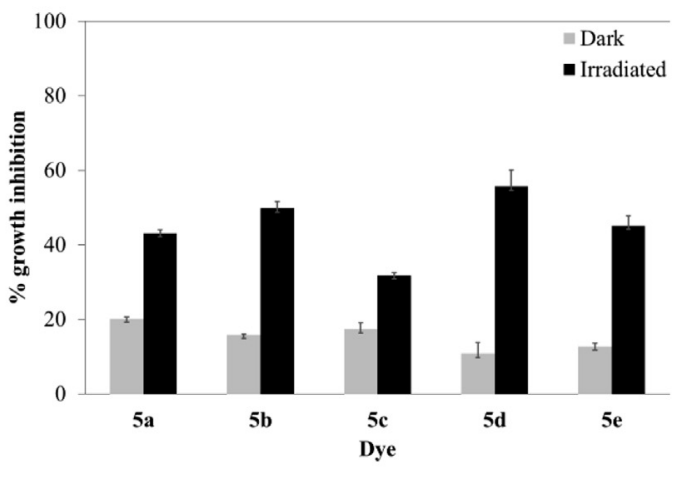

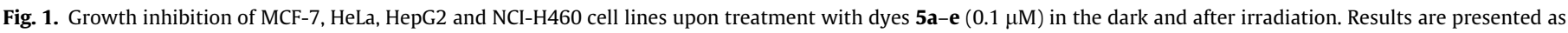
mean values \pm standard deviation $(\mathrm{SD})$.

Table 2

Cytotoxicity $\left(\mathrm{GI}_{50}\right.$ values, $\left.\mu \mathrm{M}\right)$ of compounds $\mathbf{5 a}-\mathbf{e}$ (mean $\pm \mathrm{SD}$ ).

\begin{tabular}{|c|c|c|c|c|c|c|}
\hline Compound & Condition & MCF-7 & NCI-H460 & HepG2 & HeLa & PLP2 \\
\hline $5 a$ & $\begin{array}{l}\text { Dark } \\
\text { Irradiated } \\
t \text {-Students test } p \text {-value }\end{array}$ & $\begin{array}{l}>10 \\
0.918 \pm 0.095 \\
-\end{array}$ & $\begin{array}{l}>10 \\
8.347 \pm 0.363 \\
-\end{array}$ & $\begin{array}{l}4.571 \pm 0.379 \\
0.665 \pm 0.049 \\
<0.001\end{array}$ & $\begin{array}{l}>10 \\
0.288 \pm 0.017 \\
-\end{array}$ & $\begin{array}{l}>10 \\
4.981 \pm 0.254 \\
-\end{array}$ \\
\hline $5 \mathbf{b}$ & $\begin{array}{l}\text { Dark } \\
\text { Irradiated } \\
t \text {-Students test } p \text {-value }\end{array}$ & $\begin{array}{l}7.361 \pm 0.764 \\
0.224 \pm 0.015 \\
<0.001\end{array}$ & $\begin{array}{l}8.820 \pm 0.698 \\
0.440 \pm 0.024 \\
<0.001\end{array}$ & $\begin{array}{l}7.829 \pm 0.694 \\
0.110 \pm 0.011 \\
<0.001\end{array}$ & $\begin{array}{l}>10 \\
0.097 \pm 0.001 \\
-\end{array}$ & $\begin{array}{l}3.727 \pm 0.579 \\
0.385 \pm 0.006 \\
<0.001\end{array}$ \\
\hline $5 c$ & $\begin{array}{l}\text { Dark } \\
\text { Irradiated } \\
t \text {-Students test } p \text {-value }\end{array}$ & $\begin{array}{l}5.337 \pm 0.413 \\
0.257 \pm 0.026 \\
<0.001\end{array}$ & $\begin{array}{l}0.940 \pm 0.085 \\
0.404 \pm 0.034 \\
<0.001\end{array}$ & $\begin{array}{l}4.493 \pm 0.391 \\
0.722 \pm 0.077 \\
<0.001\end{array}$ & $\begin{array}{l}>10 \\
0.088 \pm 0.006 \\
-\end{array}$ & $\begin{array}{l}0.621 \pm 0.005 \\
0.340 \pm 0.017 \\
<0.001\end{array}$ \\
\hline $5 d$ & $\begin{array}{l}\text { Dark } \\
\text { Irradiated } \\
t \text {-Students test } p \text {-value }\end{array}$ & $\begin{array}{l}0.576 \pm 0.043 \\
0.054 \pm 0.004 \\
<0.001\end{array}$ & $\begin{array}{l}0.507 \pm 0.064 \\
0.171 \pm 0.023 \\
<0.001\end{array}$ & $\begin{array}{l}7.083 \pm 0.767 \\
0.078 \pm 0.005 \\
<0.001\end{array}$ & $\begin{array}{l}2.223 \pm 0.138 \\
0.071 \pm 0.009 \\
<0.001\end{array}$ & $\begin{array}{l}0.410 \pm 0.050 \\
0.126 \pm 0.048 \\
0.001\end{array}$ \\
\hline $5 e$ & $\begin{array}{l}\text { Dark } \\
\text { Irradiated } \\
t \text {-Students test } p \text {-value }\end{array}$ & $\begin{array}{l}0.737 \pm 0.039 \\
0.239 \pm 0.034 \\
<0.001\end{array}$ & $\begin{array}{l}0.767 \pm 0.045 \\
0.455 \pm 0.012 \\
<0.001\end{array}$ & $\begin{array}{l}7.535 \pm 0.818 \\
0.271 \pm 0.014 \\
<0.001\end{array}$ & $\begin{array}{l}2.636 \pm 0.062 \\
0.273 \pm 0.007 \\
<0.001\end{array}$ & $\begin{array}{l}0.717 \pm 0.115 \\
0.471 \pm 0.044 \\
0.008\end{array}$ \\
\hline
\end{tabular}

Regarding the tests conducted in the absence of light, in the range of tested concentrations, squaraine 5a only showed inhibitory activity against the HepG2 cell line, and yet with a relatively high $\mathrm{GI}_{50}$ value. The remaining compounds presented inhibitory activity for all the cell lines tested, though in variable extension, except dyes $\mathbf{5 b}$ and $\mathbf{5 c}$ which were inactive against the HeLa cell line in the range of the concentrations used.

Upon irradiation the $\mathrm{GI}_{50}$ values decreased, in some cases very appreciably, showing significant photodynamic effect of the dyes. For compounds $\mathbf{5 a - d}$, the lowest $\mathrm{GI}_{50}$ values were obtained consistently against the HeLa cell line, while for dye 5e the lowest $\mathrm{GI}_{50}$ value was obtained against the MCF-7 cell line. The largest differences between the $\mathrm{GI}_{50}$ values obtained in the dark and upon irradiation, which are very relevant in terms of the usefulness of the photodynamic effect, were observed precisely for the HeLa cell line, with dyes $\mathbf{5 a - c ,}$ which were shown to be inactive against this cell line in the dark, in the range of the concentrations used. The HepG2 cell line turned out to be also very susceptible to the photodynamic treatment using dyes $\mathbf{5 b}$, 5d and 5e. Compound 5d presented the lowest $\mathrm{GI}_{50}$ value of all, whatever the tested cell line; nevertheless, it was not the compound that presented the highest differences between the dark and irradiated assays.

The evaluation of the cytotoxicity for PLP2 (non-tumor cells) is very important since mammalian hepatocytes still represent a 
mandatory step in the evaluation of toxic compounds that lead to the production of various metabolites, which are the ultimate cause of toxicity [30].

Apart from dye 5a which, in the range of the tested concentrations, was inactive in the absence of light and presented a $\mathrm{GI}_{50}$ value of $4.981 \pm 0.254 \mu \mathrm{M}$ upon irradiation, all compounds showed also some cytotoxicity against PLP2 cells. Nevertheless, the $\mathrm{GI}_{50}$ values obtained for the PLP2 cells were consistently higher, either in the dark or under irradiation, than those obtained against the tumor cell lines. It is worth mentioning that the locoregional nature of the photodynamic effect can diminish or even surmount the importance of the cytotoxicity observed in the non-tumor cells.

In conclusion, the aminosquaraine dyes synthesized, displaying strong absorption within the phototerapeutic window, have shown to able to inhibit the growth of the human tumor cell lines tested (MCF-7, NCI-H460, HeLa, and HepG2) upon irradiation more than in the dark, in some cases very substantially, clearly showing to display photocytotoxic activity.

The differences observed for some of the dyes between the $\mathrm{GI}_{50}$ values obtained in the absence of light and upon irradiation, turn them into potential candidates as photosensitizers for PDT, in particular compound 5a which showed the lowest toxicity for the non-tumor primary PLP2 cells.

\section{Acknowledgements}

The authors are grateful to the Foundation for Science and Technology (FCT, Portugal) and FEDER for CIMO (UID/AGR/00690/2013) and CQ-VR (UID/QUI/00616/2013) financial support.

\section{Supplementary data}

Supplementary data associated with this article can be found, in the online version, at http://dx.doi.org/10.1016/j.bmcl.2017.08. 004.

\section{References}

1. Hamblin MR, Mroz P. Advances in photodynamic therapy: basic, translational, and clinical. Norwood: Artech House; 2008.

2. Niedre M, Patterson MS, Wilson BC. Direct near-infrared luminescence detection of singlet oxygen generated by photodynamic therapy in cells in vitro and tissues in vivo. Photochem Photobiol. 2002;75:382-391.

3. Hopper C. Photodynamic therapy: a clinical reality in the treatment of cancer. Lancet Oncol. 2000;1:212-219.

4. Bown SG. Photodynamic therapy for photochemists. Philos Trans A Math Phys Eng Sci. 2013;371. 20120371.

5. Abrahamse H, Hamblin MR. New photosensitizers for photodynamic therapy. Biochem J. 2016;473:347-364.

6. Roeder B, Naether D, Lewald T, Braune M, Nowak C, Freyer W. Photophysical properties and photodynamic activity in vivo of some tetrapyrroles. Biophys Chem. 1990;35:303-312.

7. Ormond AB, Freeman HS. Dye sensitizers for photodynamic therapy. Materials. 2013;6:817-840.

8. Yagi S, Nakazumi H. Squarylium dyes and related compounds. In: Strekowski L, ed. Heterocyclic polymethine dyes: synthesis, properties and applications. Berlin: Springer, Berlin Heidelberg; 2008:133-181.
9. Avirah RR, Jayaram DT, Adarsh N, Ramaiah D. Squaraine dyes in PDT: from basic design to in vivo demonstration. Org Biomol Chem. 2012;10:911-920.

10. Ramaiah D, Joy A, Chandrasekhar N, Eldho NV, Das S, George MV. Halogenated squaraine dyes as potential photochemotherapeutic agents. Synthesis and study of photophysical properties and quantum efficiencies of singlet oxygen generation. Photochem Photobiol. 1997;65:783-790.

11. Beverina L, Salice P. Squaraine compounds: tailored design and synthesis towards a variety of material science applications. Eur J Org Chem. 2010;2010: 1207-1225.

12. Reis LV, Serrano JPC, Almeida P, Santos PF. New synthetic approach to aminosquarylium cyanine dyes. Synlett. 2002;1617-1620.

13. Reis LV, Serrano JP, Almeida P, Santos PF. The synthesis and characterization of novel, aza-substituted squarylium cyanine dyes. Dyes Pigm. 2009;81:197-202.

14. Conceição DS, Ferreira DP, Graça VC, Silva CR, Santos PF, Vieira Ferreira LF Photochemical studies of new benzothiazole- and benzoselenazole-derived aminosquarylium dyes. Tetrahedron. 2015;71:967-976.

15. Ramaiah D, Eckert I, Arun KT, Weidenfeller L, Epe B. Squaraine dyes for photodynamic therapy: mechanism of cytotoxicity and DNA damage induced by halogenated squaraine dyes plus light (>600 nm). Photochem Photobiol. 2004;79:99-104.

16. Serpe L, Ellena S, Barbero N, et al. Squaraines bearing halogenated moieties as anticancer photosensitizers: synthesis, characterization and biological evaluation. Eur J Med Chem. 2016;113:187-197.

17. Sun C-L, Liao Q, Li T, et al. Rational design of small indolic squaraine dyes with large two-photon absorption cross section. Chem Sci. 2015;6:761-769.

18. Soumya MS, Shafeekh KM, Das S, Abraham A. Symmetrical diiodinated squaraine as an efficient photosensitizer for PDT applications: evidence from photodynamic and toxicological aspects. Chem Biol Interact. 2014;222:44-49.

19. Ahn H-Y, Yao S, Wang X, Belfield KD. Near-infrared-emitting squaraine dyes with high 2PA cross-sections for multiphoton fluorescence imaging. ACS Appl Mater Interfaces. 2012;4:2847-2854.

20. Ferreira DP, Conceição DS, Fernandes F, et al. Characterization of a squaraine/chitosan system for photodynamic therapy of cancer. J Phys Chem B. 2016;120:1212-1220.

21. Gao F-P, Lin Y-X, Li L-L, et al. Supramolecular adducts of squaraine and protein for noninvasive tumor imaging and photothermal therapy in vivo. Biomaterials. 2014:35:1004-1014.

22. Jetty R, Bandera YP, Daniele MA, et al. Protein triggered fluorescence switching of near-infrared emitting nanoparticles for contrast-enhanced imaging. J Mater Chem B. 2013:1:4542-4554.

23. Ramaiah D, Eckert I, Arun KT, Weidenfeller L, Epe B. Squaraine dyes for photodynamic therapy: study of their cytotoxicity and genotoxicity in bacteria and mammalian cells. Photochem Photobiol. 2002;76:672-677.

24. Friães S, Silva AM, Boto RE, et al. Synthesis, spectroscopic characterization and biological evaluation of unsymmetrical aminosquarylium cyanine dyes. Bioorg Med Chem. 2017;25:3803-3814.

25. Soumya MS, Abraham A. Preclinical evaluation of symmetrical iiodinated squaraine dye on experimental animal models. J Glycobiol. 2013;S1:003. http:/ dx.doi.org/10.4172/2168-958X.S1-003.

26. Devi DG, Cibin TR, Ramaiah D, Abraham A. Bis(3,5-diiodo-2,4,6trihydroxyphenyl)squaraine: a novel candidate in photodynamic therapy for skin cancer models in vivo. J Photochem Photobiol B Biol. 2008;92:153-159.

27. Devi DG, Cibin TR, Abraham A. Bis (3,5-diiodo-2,4,6-trihydroxyphenyl) squaraine photodynamic therapy induces in vivo tumor ablation by triggering cytochrome c dependent mitochondria mediated apoptosis. Photodiagnosis Photodyn Ther. 2013;10:510-517.

28. Wardle B. Principles and applications of photochemistry. Chichester, West Sussex: John Wiley \& Sons, Inc.; 2009.

29. Ferreira DP, Conceicao DS, Ferreira VRA, Graca VC, Santos PF, Ferreira LFV. Photochemical properties of squarylium cyanine dyes. Photochem Photobiol Sci. 2013:12:1948-1959.

30. Abreu RMV, Ferreira ICFR, Calhelha RC, et al. Queiroz M-JRP. Antihepatocellular carcinoma activity using human HepG2 cells and hepatotoxicity of 6-substituted methyl 3-aminothieno[3,2-b]pyridine-2carboxylate derivatives: in vitro evaluation, cell cycle analysis and QSAR studies. Eur J Med Chem. 2011;46:5800-5806. 